\title{
Kajian Awal Manajemen Aset bagi Instalasi Pengolahan Air Limbah Denpasar di Suwung Bali
}

\author{
Preliminary Review of Asset Management for Denpasar Sewerage \\ Instalation in Suwung Bali
}

\author{
Andi Candra Septaprasetya ${ }^{1, a)}$, Ayu Rahmaniyah ${ }^{2, b)}$, Ratri Ayu ${ }^{3, \mathrm{c})}$, Riska Dewi \\ Wijayanti $^{4, \mathrm{~d})}$ \& Hitapriya Suprayitno ${ }^{5, \mathrm{e})}$ \\ ${ }^{1)}$ Dinas Pekerjaan Umum Binamarga dan Pematusan, Kota Surabaya. \\ ${ }^{2}$ Bappelitbangda, Kota Pasuruan. \\ ${ }^{3}$ Balai Diklat PU Wilayah IV, BPSDM, Kementerian PUPR. \\ ${ }^{4)}$ Balai Prasarana Permukiman Wilayah Jawa Timur, DitJen Bina Marga, Kementerian PUPR. \\ ${ }^{5}$ Departemen Teknik Sipil, FTSLK, Institut Teknologi Sepuluh Nopember (ITS), Surabaya.
}

Koresponden : ${ }^{a}$ bearelits42@gmail.com, ${ }^{b}$ ayuramukti@gmail.com, ${ }^{c}$ ratriayu.pu@gmail.com, d)riska.dw@gmail.com \& ${ }^{e}$ suprayitno.hita@gmail.com

\begin{abstract}
ABSTRAK
Perkembangan sektor pariwisata dan laju pembangunan daerah wisata di Bali diikuti juga dengan timbulnya berbagai masalah lingkungan. Pencemaran yang disebabkan oleh pesatnya pertambahan penduduk, aktivitas industri jasa dan pariwisata, membuat semakin menurunnya kualitas sanitasi lingkungan. Untuk itu pemerintah Provinsi Bali bekerja sama dengan Pemerintah Pusat dan Pemerintah Jepang menyelenggarakan pembangunan Denpasar Sewerage Development Project (DSDP). DSDP merupakan proyek pembangunan jaringan limbah cair domestik yang melayani Kota Denpasar dan Kabupaten Badung. Proyek DSDP terdiri atas pembangunan Instalasi Pengolahan Air Limbah (IPAL) di Sanur, pembangunan jaringan utama, dan 2 (dua) stasiun pompa di Kuta dan Sanur serta sambungan rumah. Setelah berfungsi proyek tersebut diserahkan ke Pemerintah Provinsi untuk dikelola dan dinamakan IPAL Denpasar. Kajian penerapan manajemen aset ini dilakukan dengan melihat konsep pengembangan dan pengelolaan IPAL secara keseluruhan sehingga dapat memberikan rekomendasi pengelolaan IPAL. Penelitian ini dilakukan dengan memberikan gambaran tentang kondisi eksisting aset dan penerapan manajemen aset di IPAL berdasarkan Pandangan Dasar Infrastruktur Publik untuk Manajemen Aset Infrastruktur dengan memperhatikan 6 (enam) konsep dasar meliputi; Sistem Infrastruktur, Fungsi Infrastruktur, SupplyDemand Infrastruktur, Sistem Operasi Infrastruktur, Deteriorasi dan Pemeliharaan Infrastruktur, dan Siklus-Hidup Infrastruktur. Hasil review penerapan manajemen aset ini pengembangan dan pengelolaan infrastruktur DSDP telah sesuai dengan konsep dasar dalam Pandangan Dasar Infrastruktur Publik untuk Manajemen Aset Infrastruktur.
\end{abstract}

Kata Kunci : manajemen aset infrastruktur \& fasilitas, instalasi pengolhan air limbah, kajian manajemen asset.

\section{PENDAHULUAN}

Bali adalah ikon pariwisata nasionaldan daerah tujuan utama wisata berskala internasional. Perkembangan sektor pariwisata dan laju pembangunan daerah wisata di Bali diikuti juga dengan timbulnya berbagai masalah lingkungan. Pencemaran yang disebabkan oleh pesatnya pertambahan penduduk, aktivitas industri jasa dan pariwisata, membuat semakin menurunnya kualitas sanitasi lingkungan. Hasil Studi DSDP tahun 1997-1998, 
menyebutkan telah terjadi penurunan kualitas air (sungai, air tanah, dan laut) di bagian selatan dan pusat Kota Denpasar, terutama sumur penduduk di mana $71 \%$ sumur penduduk di lokasi pengujian telah terpolusi bakteri (Fecal Coliform). Untuk itu pemerintah Provinsi Bali bekerja sama dengan Pemerintah Pusat dan Pemerintah Jepang menyelenggarakan pembangunan Denpasar Sewerage Development Project (DSDP). DSDP merupakan proyek pembangunan jaringan limbah cair domestik yang melayani Kota Denpasar dan Kabupaten Badung.

Pembangunan DSDP merupakan kerjasama Pemerintah Pusat dengan Jepang melalui Japan Bank For International Cooperation (JBIC) yang diawali sejak 1991-1992 dengan pembuatan master plan dan studi kelayakan yang disusun oleh Pemerintah didampingi oleh Japan International Cooperation Agency (JICA). Naskah Perjanjian Luar Negeri (NPLN) untuk kegiatan ini ditandatangin tahun 1997 dilanjutkan dengan pembangunan DSDP I tahun 2004-2008 dan pembangunan DSDP II tahun 2009-2014. Proyek DSDP I terdiri atas pembangunan Instalasi Pengolahan Air Limbah (IPAL) di Sanur, pembangunan jaringan utama, dan 2 (dua) pumping station di Kuta dan Sanur serta sambungan rumah pada kawasan tahap I. Proyek DSDP II merupakan kelanjutan dari proyek DSDP I, dengan perluasan area pelayanan sistem pengelolaan air limbah terpusat (sewerage system) meliputi Kota Denpasar dan Kabupaten Badung (kawasan Sanur dan Kuta), Provinsi Bali.

Pemerintah Pusat menghibahkan keseluruhan Instalasi DSDP kepada Pemerintah Provinsi Bali. Pengelolaan dan Pemeliharaan DSDP menjadi tanggung jawab Pemerintah Provinsi Bali melalui Unit Pelayanan Teknis (UPT) Provinsi yang menjadi Badan Layanan Umum (BLU) Daerah pada tahun 2007. Selanjutnya, unit layanan ini dinamakan sebagai Instalasi Pengolahan Air Limbah (IPAL) Denpasar. Dalam rangka pengelolaan aset infrastruktur diperlukan penerapan manajemen aset yang terstruktur guna mengoptimasi keberfungsian dan keberlanjutan aset infrastruktur yang ada (Munizar, 2018).

Oleh karena itu sangat diperlukan kajian penerapan Prinsip Manajemen Aset pada IPAL Denpasar untuk dapat mengetahui keberfungsian dan potensi keberlanjutan aset infrastruktur yang ada. Kajian penerapan Prinsip Manajemen Aset ini dilakukan dengan melihat konsep pengembangan dan pengelolaan DSDP secara keseluruhan sehingga dapat memberikan rekomendasi pengelolaan DSDP.

\section{TINJAUAN PUSTAKA}

\section{Manajemen Aset Infrastruktur \& Fasilitas}

Manajemen adalah serangkaian proses yang terdiri dari perencanaan, pengorganisasian, pelaksanaan, pengendalian dan penganggaran (Nawawi,2006). Definisi dari aset adalah sesuatu yang memiliki nilai ekonomi, nilai komersial atau nilai tukar yang dimiliki oleh suatu badan usaha, agen atau individu. Ada dua jenis aset: aset berwujud dan tidak berwujud (Siregar, 2004). Aset infrastruktur adalah aset yang melayani kepentingan publik, biaya pengeluaran untuk aset infrastruktur ditentukan oleh kesinambungan penggunaan aset terkait, seperti jalan, jembatan, dan sebagainya (Hariyono, 2007). Lingkup implementasi pengelolaan aset yang dimaksud meliputi perencanaan kebutuhan dan penganggaran, pengadaan, penggunaan, pemanfaatan, pengamanan dan pemeliharaan, penilaian, penghapusan, pemindahtanganan, penatausahaan dan pembinaan, pengawasan, dan pengendalian. Menurut (Sugiama, 2013), manajemen aset adalah ilmu dan seni untuk memandu manajemen kekayaan yang mencakup proses perencanaan kebutuhan aset, memperoleh, menginventarisir, mengaudit, menilai, mengoperasikan, memelihara, memperbarui atau menghilangkan untuk memindahkan aset secara efektif dan efisien. Sedangkan Manajemen Aset Infrastruktur \& Fasilitas (MAIF) sendiri didefinisikan dengan cara berbeda di berbagai referensi. Dalam kasus Infrastruktur Publik Indonesia, dua definisi yang berbeda akan diambil sebagai referensi. Manajemen Aset Infrastruktur (MAI) memiliki definisi sebagai suatu program atau pengetahuan untuk mengelola, suatu infrastruktur agar tetap bisa menjalankan fungsinya 
dengan baik secara terus menerus sepanjang masih dibutuhkan, secara ekonomis, efisien, dan efektif dan memenuhi prinsip green atau sustainability. MAI harus didasarkan pada pengetahuan yang baik atas karakteristik infrastruktur yang sedang dikelola atau dibahas. Karakteristik infrastruktur bisa sangat berbeda antara yang satu dengan yang lain. Karakteristik penting infrastruktur yang harus dikenali dengan baik antara lain adalah: tipe, kelas, fungsi, struktur, ekonomi, siklus hidup, operasi, pemeliharaan, penghapusan (Soemitro \& Suprayitno, 2018; Suprayitno \& Soemitro, 2018). Peraturan Pemerintah Nomor 27 Tahun 2014, Pasal 3 menetapkan bahwa Pengelolaan Perbendaharaan Milik Negara dan Daerah (BMN) dijalankan berdasarkan prinsip fungsionalitas, kepastian hukum, transparansi, efisiensi, akuntabilitas, dan kepastian nilai. Manajemen BMN terdiri dari kebutuhan dan perencanaan anggaran pengadaan, akuisisi, pemanfaatan, penyimpanan dan pemeliharaan, penilaian, penyerahan, likuidasi, pembuangan, administrasi, pengawasan dan pengendalian (PP 27/ 2014). Di Indonesia pengelolaan aset milik negara diatur dalam Peraturan Pemerintah Republik Indonesia Nomor 27 tahun 2014 tentang Pengelolaan Barang Milik Negara/Daerah, serta Permendagri Nomor 17 tahun 2007 tentang Pedoman Pengelolaan Barang Milik Daerah.

\section{Pandangan Dasar Sistem Infrastruktur untuk MAI}

Pandangan Dasar Sistem Infrastruktur harus didasarkan pada fakta bahwa infrastruktur dibangun karena wilayah tertentu membutuhkan infrastruktur. Jadi infrastruktur dibangun untuk melayani area yang dilayani. Di wilayah yang dilayani, ada pengguna infrastruktur. Infrastruktur merupakan bagian integral dari suatu daerah. Sistem infrastruktur terdiri dari infrastruktur, wilayah yang disediakan, dan para pengguna (Suprayitno \& Soemitro, 2019).

Menurut Suprayitno dan Soemitro (2019), pada prinsipnya Pandangan Dasar Infrastruktur Publik untuk Manajemen Aset Infrastruktur terdiri dari beberapa konsep dasar berikut :

- Sistem Manajemen Aset Infrastruktur

- Sistem Infrastruktur

- Fungsi Infrastruktur

- Supply-Demand Infrastruktur

- Sistem Operasi Infrastruktur

- Deteriorasi dan Pemeliharaan Infrastruktur

- Life-Cycle Infrastruktur

- Ekonomi Infrastruktur

- Taxonomy Infrastruktur

Siklus Hidup Infrastruktur sendiri dimulai dari ide kebutuhan infrastruktur, diikuti oleh perencanaan infrastruktur, desain infrastruktur, konstruksi infrastruktur. Setelah infrastruktur dibangun, infrastruktur kemudian dapat dimanfaatkan, berarti dioperasikan dan dipelihara. Tetapi, sebelumnya, infrastruktur perlu disertifikasi dan diadministrasikan. Selama pemanfaatan, setiap kali infrastruktur perlu dievaluasi untuk mengembangkan program infrastruktur tahunan. Pada kondisi tertentu, infrastruktur dapat dihapuskan, jika infrastruktur tidak lagi diperlukan untuk melayani wilayah yang dilayani (Suprayitno \& Soemitro, 2019).

\section{Pengelolaan Air Limbah}

Air limbah domestik adalah air limbah yang berasal dari usaha dan/ atau kegiatan pemukiman, rumah makan, perkantoran, perniagaan, apartemen, dan asrama (Permen PUPR No. 04/PRT/M/2017). Dalam Permen PU No. 16 / 2008, juga terdapat tujuan atau visi dari pengelolaan air limbah yaitu untuk mewujudkan masyarakat sehat dalam lingkungan yang lestari. Sedangkan indikator yang dipakai dalam keberhasilan pencapaian tujuan dan visi tersebut adalah:

1. Rendahnya angka penyakit yang ditularkan melalui media air 
2. Meningkatnya kualitas lingkungan permukiman

3. Terlindungnya sumber air baik air permukaan maupun air tanah dari pencemaran

Menurut Spellman (2003), tujuan atau fungsi utama dari pengolahan air limbah adalah untuk melindungi kesehatan dan kesejahteraan masyarakat. Operasi pengolahan air dan air limbah telah mencapai tujuan ini dengan ipencapaian sub-fungsi sebagai berikut :

1. Pencegahan penyakit dan gangguan kondisi lingkungan

2. Menghindari kontaminasi pasokan air bersih dan air yang dapat dilayari

3. Pemeliharaan air bersih untuk kelangsungan hidup ikan, mandi, dan rekreasi

4. Konservasi kualitas air untuk penggunaan masa depan

\section{Pengoperasian dan Pemeliharaan Instalasi Pengolahan Air Limbah}

Air limbah yang dibahas dalam penelitian ini adalah air limbah domestik. Sedangkan instalasi pengolahan air limbah yang selanjutnya disingkat IPAL adalah serangkaian kegiatan pengelolaan air limbah domestik dalam satu kesatuan dengan prasarana dan sarana pengelolaan air limbah domestik. Dalam IPAL terdapat standar operasional dan prosedur yang harus dilaksanakan demi tercapainya fungsi infrastrukturnya yaitu diantaranya sebelum mengoperasikan instalasi pengolahan air limbah (IPAL), Kepala bagian IPAL yang bertanggung jawab penuh atas instalasi, harus mengorganisir dan menginstruksikan tindakantindakan yang tepat kepada personel-personel yang bertanggung jawab atas pengoperasian instalasi tersebut. Beberapa standar pengoperasian dan pemeliharaan IPAL adalah sebagai berikut (Anonim, 2019).

1. Sistem kelistrikan: Pasokan listrik biasanya dari jaringan PLN, tetapi jika diperlukan bisa juga di backup dengan unit genset tersendiri. Jika dengan dua sumber, maka penel listrik untuk power supply juga dipasang. Semua peralatan mesin pada suatu plant IPAL dikontrol dan dimonitor melalui panel listrik yang sudah diatur dan disetel sedemikian rupa, baik susunan peralatan listrik dan masing-masing kapasitasnya serta kabel sambungannya. Kepala IPAL harus membuat plakat berisi urut-urutan cara menghidupkan dan mematikan peralatan listrik untuk pengoperasian IPAL, plakat ditempelkan pada pintu panel listrik, supaya mudah terlihat dan terbaca.

2. Pengoperasian unit pretreatment: (1) proses awal dimulai dengan screen awal dengan saringan, kotoran diambil dan dibuang paling tidak satu kali sehari jika menggunakan bar screen dan sistem manual, dan jika memakai saringan mekanis juga dibuang sekali sehari; (2) dilanjutkan dengan penggunaan pompa angkat dimana pada suatu IPAL biasanya selalu terdapat 3 unit pompa angkat, 2 unit pompa untuk dioperasikan dan 1 unit pompa untuk standby. Standby bisa berarti pompa bisa dioperasikan sewaktu-waktu, misal dalam kondisi air di stasiun pompa dalam keadaan banjir, atau bila salah satu pompa mengalami kerusakan atau macet, dan lain sebagainya. Pengoperasian pompa angkat tergantung tinggi permukaan air di stasiun pompa; (3) Screen tahap kedua (setelah pompa) kotoran diambil dan dibuang paling tidak satu kali sehari jika menggunakan bar screen dan sistem manual, dan jika memakai saringan mekanis juga dibuang sekali sehari; (4) Penangkap butiran kasar (Grit Chamber): Bila jenis grit chamber yang digunakan adalah sistem kanal, dan grit diambil/dikuras dengan pompa pasir jenis submersible, pompa pasir jenis ini biasanya digantungka pada dereklistrik/chain hoist; (5) Pemisah tipe pusaran \& tipe ulir/cyclone separator \& screw separator: rangkaian peralatan dari sistem pemisahan grit dari grit chamber sistem kanal, pada sistem kolam detritus grit sudah dicuci dan dikumpulkan pada ujung rak pencuci; (6) Saringan kasar grit chamber: biasanya pada ujung grit chamber sistem kanal terdapat lagi bar screen yang menyaring plastik dan kotoran mengambang lainnya dalam influen; (7) Bak pembagi: Pada bak pembagi/distribution chamber, terdapat 2 (dua) pintu air/gate (jika ada 2 jalurpengolahan), setiap gate/pintu air berfungsi untuk 
menyalurkan air limbah ke salah satu jalur/baris kolam stabilisasi; (8) Perangkat lemak/grease trap: Sebaiknya grease trap dipasang/berada pada setiap rumah, sehingga resiko penyumbatanpada jaringan perpipaan jadi minim/kecil, sehingga pemeliharaan jaringan perpipaan secara keseluruhan akan menjadi ringan. Pemeliharaan grease trap menjadi tanggung jawab masing masing rumah tangga; (9) Bak perata/ ekualisasi: Bak ekualisasi berfungsi sebagai pengumpul air limbah selama 24 jam dari cakupan wilayah kerja IPAL yang ada, juga sebagai kolam pengumpul sebelum dipompakan ke unit pengolahan berikutnya. Dari bak ekualisasi ini, air limbah dipompa masuk ke unit pengolahan selama 24jam. Tidak ada operasi khusus pada bak ekualisasi ini; (10) Pompa angkat/lift pump: terdapat 3 (tiga) unit pompa angkat, 2 (dua) unit pompa untuk dioperasikan (bergantian) dan 1 (satu) unit pompa untuk standby. Standby bisa berarti pompa bisa dioperasikan sewaktu waktu, misal dalam kondisi air di pump station tinggi/ banjir, ataubila salah satu pompa mengalami kerusakan atau macet, dan lain sebagainya; (11) Pengatur Aliran/flow control: Konstruksinya biasanya dengan $V$-notch, sehingga bisa diatur debit yang diinginkan masuk keunit IPAL.Atur ketinggian permukaan air pada $V$-Notch lalu Ukur debit yang keluar, jika sudah tercapai debit yang sesuai, kencangkan baut gate Vnotch tersebut.

3. Pengoperasian kolam stabilisasi limbah: Sistem ini pada umumnya tidak dilengkapi peralatan mekanis, maka pengoperasian dan pemeliharaan sistem ini relativ mudah, sederhana, dan murah. Mengoperasikan kolam stabilisasi membutuhkan tenaga orangorang yang terlatih. Pengoperasian dan perawatan mencakup memulai pengoperasian kolam, mengelola kondisi permukaan kolam, menjaga tanggul dan lokasi site kolam, dan juga menguras kolam serta membuang lumpur.

4. Pemeliharaan kolam stabilisasi limbah: Pada permukaan kolam akan muncul lapisan scum dan lapisan-lapisan lumpur (sludge) yang mengambang. Algae bisa berkembangbiak dan membentuk lembaran-lembaran yang mengambang di permukaan dan menghalangi sinar matahari dan merusak efisiensi kolam.Lembaran-lembaran algae yang mati bias membusuk dan menimbulkan bau tak sedap. Lembaran-lembaran tersebut harus dipecah dan dibuyarkan dengan semprotana ir dari selang atau dengan kait. Jika diperlukan, gunakan perahu untuk menjangkau lembaran-lembaran tersebut. Lakukan pemeriksaan tanggul dan lokasi kolam setiap satu atau dua minggu. Selain kondisi permukaan kolam seperti yang sudah dibahas sebelumnya, ada beberapa hal yang perlu diperiksa. Jika ada masalah, perbaiki segera. Selain itu ketebalan lumpus harus diperiksa tiap tahunnya agar tidak menggangu proses alamiah dari kolam tersebut dan bisa menyumbat pipa inlet. Alat untuk mengoperasikan dan memelihara sebuah kolam kolam stabilisasi harus disimpan digudang di dekat lokasi kolam. Bersihkan semua alat dan simpan dalam kondisi yang baik.Buatlah catatan yang menunjukkan semua kegiatan pemeliharaan. Begitu kolam mulai berfungsi dalam kondisi yang mapan, pemeliharaan rutin yang diperlukan adalah pemeliharaan minimal, walau demikian sangat diperlukan supaya dapat beroperasi dengan baik. Sedangkan untuk pemeliharaan peralatan dilakukan secara inspeksi harian (pemeriksaan harian ditetapkan pada jam yang sama setiap hari untuk melihat apakah ada kelainan/ anomali pada mesin atau peralatan yang sedang berkerja. Hasil inspeksidicatat dalam Tabel Inspeksi Harian) dan inspeksi periodik (dilakukan menurut standar inspeksi yang sudah ditetapkan sebelumnya. Ini dimaksudkan untuk memahami kondisi abrasi / ke-aus-an dan kelapukan pada mesin dan peralatan yang ada, sehingga dapat dilakukan perbaikan dan penggantiannya secara sistematis). Untuk pemeliharaan trunk sewer/saluran limbah utama, patroli harus memeriksa setiap manhole (lubang masuk gorong-gorong) di trunk sewer secaraperiodik. Saat pemeriksaan, semua sampah seperti grit, kantong plastik, atau benda asinglainnya yang terkumpul di manhole harus dibuang sampai tuntas. 
5. Pengoperasian unit pengolahan air limbah: harus dipastikan bahwa pada proses pengendapan, lumpur tersalurkan dengan baik dengan baik kekolam pengering lumpur, serok lumpur secara priodik. Teknologi pengolahan secara Anaerobik sebagai pengolahan awal/primary treatment padaIPAL komunal, bertujuan untuk mengurangi/menekan biaya operasi yang timbul, bandingkan jika hanya memakai pengolahan aerobik (misal RBC) saja. Teknologi yang biasa dipakai adalah tangki septik model baffle atau anaerobik filter. Pada kedua teknologi tersebut tidak diperlukan sistem pengoperasian khusus, setelah air limbahmasuk secara kontinyu lewat kotak pengontrol aliran, maka pemeliharaan rutin adalah dengan menyedot lumpur dari kolam anaerobik, setiap tahun. Untuk Unit RBC (Rotating Biological Contactor) bisa diletakkan selevel dengan unit anaerobik, dibawah tanah, dan bisa juga diletakandi atas tanah ataupun di atas bangunan. Peletakan unit RBC bergantung pada kondisi lokasiyang ada. Selanjutnya untuk pengoperasian bak pengendapan akhir/scondary clarifier konstruksinya bisa lebih kecil dibanding pengendapan awal, karena tidak didesain untuk menyimpan lumpur dalam jang waktu tertentu (1 tahun). Endapan lumpur pada kolam ini dipompa setiap hari dan dimasukkan pada bak pengendapan awal, pompa bisa menggunakan pompa lumpor atau jenis pompa angkat lainnya. Sedangkan untuk unit disenfeksi untuk IPAL komunal dipakai yang sedehana saja seperti tipe kotak atau kanal dengan tablet klorin. Untuk perawatan sistem proses hindari masukan deterjen dan minyak dalam jumlah banyak kedalam $\mathrm{RBC}$, gunakan deterjen yang biodegradable, jangan membuang minyak dalam jumlah yang banyak di pipa inlet, lumpur dan padatan yang terapung harus dibuang minimum tiga bulan sekali, jangan masukan bahan-bahan yang tidak dapat diolah secara biologis, jangan masukan bahan-bahan kimia kedalam sistem karena dapat mematikan bakteri yangdigunakan untuk pengolahan dan jangan hubungkan aliran listrik lain ke panel kontrol karena akan merusak sistem kontrol.

6. Operasi dan pemeliharaan oxydation ditch: Monitor kualitas efluen sesuai dengan standar aliran dan/atau standar efluenyang berlaku, analisis proses operasi (seperti MLSS, DO, selimut lumpur, settleability), Pembersihan rutin screen, pelimpah, mekanisme skimmer, dinding tangki, dankomponen lainnya. Monitoring perlu dilakukan untuk membandingkan indikator kualitas yang terjadi dan yang diharapkan. Tekniknya dilakukan secara visual (dengan memperhatikan Warna, Bau, Buih, Pertumbuhan alga, Pola penyebaran aerator, Kebeningan efluen, Gelembung udara, Bahan-bahan yang mengapung dan Akumulasi zat padat) serta secara analisis (DO, $\mathrm{BOD}, \mathrm{COD}$, tes laju DO up-take, SS dan VSS di mixed liquor, nutrien, $\mathrm{pH}$, minyak dan lemak, temperatur, analisis mikroskopik, kedalaman selimut lumpur, asiditas dan alkalinitas, jar test, debit, waktu detensi serta kapasitas pembubuhan kima).

\section{METODA PENELITIAN}

Penelitian ini dilakukan dengan memberikan gambaran tentang kondisi eksisting aset dan penerapan manajemen aset di DPSP berdasarkan Pandangan Dasar Infrastruktur Publik untuk Manajemen Aset Infrastruktur dengan memperhatikan 6 (enam) konsep dasar meliputi; Sistem Infrastruktur, Fungsi Infrastruktur, Supply-Demand Infrastruktur, Sistem Operasi Infrastruktur, Deteriorasi dan Pemeliharaan Infrastruktur, dan Life-Cycle Infrastruktur. Selanjutnya akan dilihat penerapan menajemen aset sesuai dengan tahapan dalam pandangan dasar aset yang ada pada studi literatur dan akan dihasilkan rekomendasi bagi DSDP terkait keberfungsian aset. Data dalam penelitian ini adalah data primer dari UPT pengelola DSDP. 


\section{ANALISIS PENELITIAN}

\section{Kondisi Eksisting IPAL Denpasar}

\section{Gambaran Umum}

Adanya perkembangan penduduk dan juga industri pariwisata tanpa diimbangi dengan sarana penanganan air limbah yang memadai akan memperburuk kondisi lingkungan. Hal ini terjadi di wilayah Denpasar dan sekitarnya, dimana pembangunan hotel dan restoran bagi wisatawan telah mengakibatkan kepadatan kawasan terbangun yang sangat tinggi. Untuk itu, tahun 1993 telah disusun Master Plan dan Studi Kelayakan untuk penanganan air limbah dengan dana hibah dari JICA untuk tujuan konservasi kualitas air sungai dan air laut, khususnya di kota Denpasar dan sekitarnya. Selanjutnya detail desain proyek DSDP (Denpasar SewerageDevelopment Project) dengan wilayah pelayanan pusat kota Denpasar dan dua daerah wisata Sanur dan Kuta mulai dilaksanakan sejak tahun 1997, dengan dana pinjaman pemerintahan Jepang (JBIC) dan dana pemerintahan Indonesia (Pemerintah Pusat, Pemerintah Propinsi Bali, Kota Denpasar dan Kabupaten Badung).

Dalam Master Plan, yang disusun pada tahun 1993, ditetapkan wilayah pelayanan meliputi kawasan Denpasar, Sanur, dan Kuta dengan total luas area 4.155 ha yang akan melayani 103.200 jiwa. Karena area yang dilayani sangat luas sehingga dibuat pentahapan dalam proses pembangunan. Pada dasarnya pembangunan dibagi dalam 2 tahap, namun pada pelaksanaan perencanaan dan pembangunan didasarkan atas tingkat urgenitas wilayah tersebut. Daerah pusat kota, tingkat hunian dan pariwisata yang tinggi menjadi prioritas yang utama.Area perencanaan tahap I seluas 474 ha berada di bagian selatan Sanur. Daerah ini merupakan pusat pariwisata daerah Sanur. Pembangunan tahap I berakhir pada pertengahan tahun 2008.

Pembangunan DSDP yang dilaksanakan mencakup pekerjaan-pekerjaan sebagai berikut: Instalasi Pengolahan Air Limbah (IPAL) / WastewaterTreatment Plant dengan kapasitas pengolahan $51.000 \mathrm{~m} 3 /$ hari; jaringan pipa air limbah (sewer network) $\varnothing 200-1200 \mathrm{~mm}$ dengan panjang total $130 \mathrm{~km}$; Rumah pompa (pumping station) di Sanur dan Kuta; Sambungan Rumah (house connection) sebanyak 10.000 unit. Skema jaringan infrastruktur \& fasilitas IPAL disampaikan pada Gambar 1 sebagai berikut.

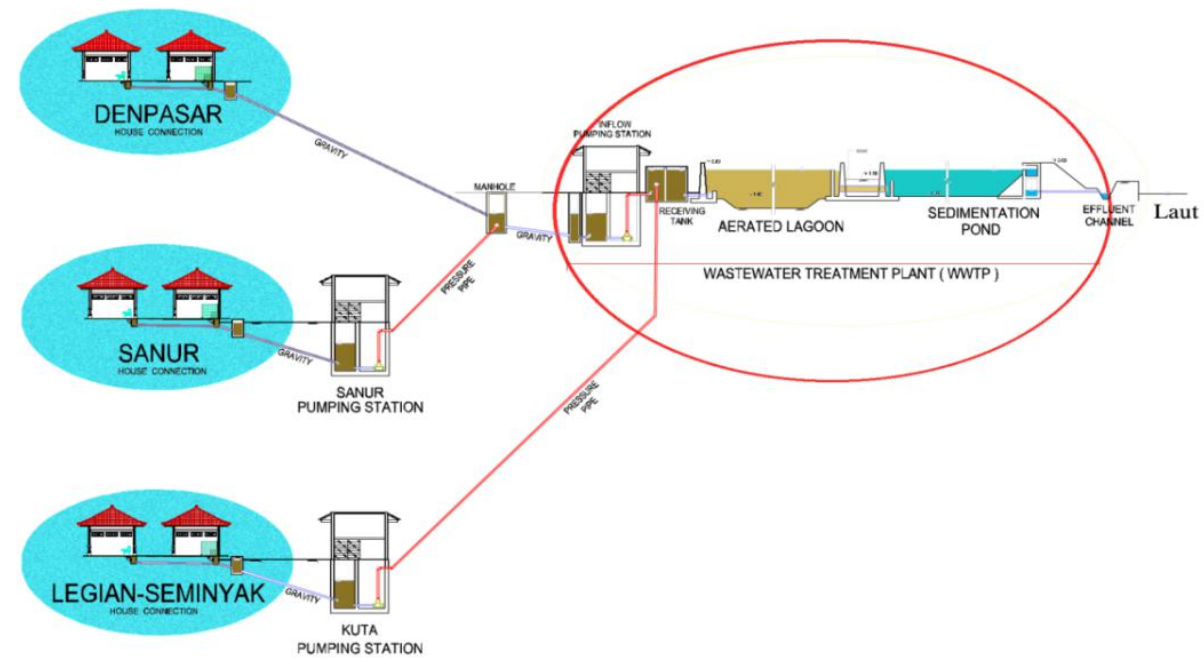

Gambar 1. Skema Sistem Pengolahan Air Limbah DSDP (UPT PAL, 2019) 


\section{$\underline{\text { Daerah Pelayanan IPAL Denpasar }}$}

Daerah Pelayanan IPAL Denpasar meliputi tiga kawasan, yaitu : Kawasan Pusat Kota Denpasar, kawasan Sanur dan Kawasan Seminyak Legian. Daerah Pelayanan ini selanjutnya akan diperluas ke Kawasan Kuta dan Kawasan Pusat Utara Kota Denpasar. Selanjutnya, perluasan akan dilakukan unutk meliputi seluruh Kota Denpasar, seluruh Kawasan Kuta Seminyak Legian dan seluruh Kawasan Pantai Sanur. Gambaran Daerah Pelayanan IPAL Denpasar disampaikan pada Gambar 2 sebagai berikut.

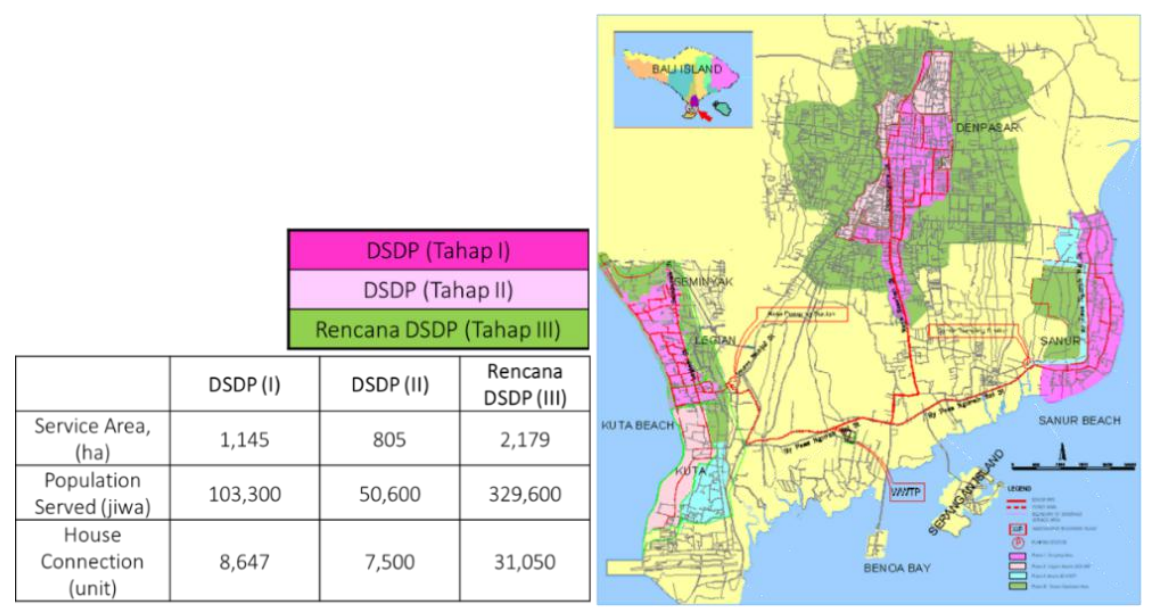

Gambar 2. Daerah Pelayanan IPAL Denpasar (UPT PAL, 2019)

\section{$\underline{\text { Tarif Pelayanan IPAL Denpasar }}$}

Tarif pelayanan merupakan imbalan atas layanan yang diberikan oleh Unit Pelaksana Teknis Pengelolaan Air Limbah sebagai pengelola IPAL Denpasar. Penetapan tarif layanan mempertimbangkan kontinuitas dan pengembangan layanan, daya beli masyarakat, serta kompetisi yang sehat. Dasar hukum penyusunan tarif pelayanan IPAL Denpasar adalah sebagai berikut.
a. Undang Undang Nomor 28 Tahun 2009 Tentang Pajak Daerah dan Retribusi Daerah
b. Peraturan Daerah Provinsi Bali Nomor 2 Tahun 2011 Tentang Retribusi Jasa Umum
c. Peraturan Gubernur Bali Nomor 38 Tahun 2012 Tentang Petunjuk Pelaksanaan Perda
Prov Bali No. 2 Tahun 2011 Tentang Retribusi Jasa Umum
d.PERGUB Bali No 6 Tahun 2017 Tentang Tarif Pengolahan Limbah Cair Pada Unit
Pelaksana Teknis Pengelolaan Air Limbah.

Tarif Pelayanan IPAL Denpasar terbagi kedalam dua golongan : Layanan dengan menggunakan Jaringan Pipa (Layanan Perpipaan) dan Layanan tidak menggunakan Jaringan Pipa (Layanan Non Perpipaan). Layanan Non Perpipan menggunakan Truk Septic Tank.

Layanan Perpipaan dibagi kedalam 7 golongan Pelanggan dengan tariff yang berbeda. Ketujuh golongan tersebut adalah : Kegiatan Sosial, Rumah Tangga, Instansi Perkantoran, Hotel, Restoran, Komersial, dan Fasilitas Umum. Daftar Tarif Pelanggan disampaikan pada Tabel 1 sebagai berikut. 
Tabel 1. Tarif Pelayanan DSDP

\begin{tabular}{|c|c|c|}
\hline No & Klasifikasi Pelanggan & Tarif \\
\hline A & Perpipaan & \\
\hline I & $\begin{array}{l}\text { Sosial } \\
\text { - Yayasan Sosial, Panti Asuhan, Sekolah Banjar }\end{array}$ & 10.000 \\
\hline \multirow[t]{4}{*}{ II } & Rumah Tangga & \\
\hline & $\begin{array}{l}\text { Tipe A } \\
\text { Perumahan yang di mukanya terdapat jalan yang } \\
\text { kelebarannya termasuk saluran got dan berm di bawah } 7 \mathrm{~m}\end{array}$ & 15.000 \\
\hline & $\begin{array}{l}\text { Tipe B } \\
\text { Perumahan yang di mukanya terdapat jalan yang } \\
\text { kelebarannya termasuk saluran got dan berm antar } 7-10 \mathrm{~m}\end{array}$ & 20.000 \\
\hline & $\begin{array}{l}\text { Tipe } \mathrm{C} \\
\text { Perumahan yang di mukanya terdapat jalan yang } \\
\text { kelebarannya termasuk saluran got dan berm di atas } 10 \mathrm{~m}\end{array}$ & 25.000 \\
\hline III & Instansi Perkantoran & 70.000 \\
\hline \multirow[t]{4}{*}{ IV } & Hotel & \\
\hline & 1. Bintang (tarif diperhitungkan untuk setiap kamar) & 100.000 \\
\hline & $\begin{array}{l}\text { 2. Non Bintang (tarif diperhitungkan untuk setiap } \\
\text { kamar) }\end{array}$ & 50.000 \\
\hline & 3. Penginapan/Losmen & 150.000 \\
\hline \multirow[t]{4}{*}{$\mathrm{V}$} & Restoran & \\
\hline & 1. Mempunyai maksimal 50 tempat duduk & 400.000 \\
\hline & 2. Mempunyai tempat duduk antara 50-100 & 500.000 \\
\hline & 3. Mempunyai tempat duduk lebih dari 100 & 700.000 \\
\hline \multirow[t]{4}{*}{ VI } & Komrsial/Niaga & \\
\hline & 1. Kecil (SIUP Kecil) & 45.000 \\
\hline & 2. Sedang (SIUP Sedang) & 100.000 \\
\hline & 3. Besar (SIUP Besar) & 150.000 \\
\hline VII & Fasilitas Umum & 40.000 \\
\hline \multirow[t]{3}{*}{$\mathrm{B}$} & Non Perpipaan & \\
\hline & $\begin{array}{l}\text { 1. Pelayanan pengurasan Septic Tank dengan truk } \\
\text { tinja per m3 }\end{array}$ & 150.000 \\
\hline & $\begin{array}{l}\text { 2. Pelayanan Truk Tinja ya membuang limbah ke } \\
\text { IPAL Suwung per tangki (maksimal truk roda 6) }\end{array}$ & 75.000 \\
\hline
\end{tabular}

Sumber: PerGub Bali 38 / 2012

\section{Jumlah Pelanggan IPAL Denpasar}

Pada tahun 2019, jumlah pelanggan IPAL Denpasar sebanyak 13.356 sambungan. Jumlah ini didominasi oleh katagori Sambungan Rumah Tangga Tipe A dan Tipe B, serta Sambungan Komersial Tipe N1. Data pelanggan disampaikan pada Tabel 2 sebagai berikut. 
Tabel 2. Rekapitulasi Pelanggan DSDP

\begin{tabular}{|c|l|r|}
\hline No & \multicolumn{1}{|c|}{ Kategori } & Jumlah \\
\hline 1 & Perpipaan Sosial (PS) & 72 \\
\hline 2 & Rumah Tangga type A (RTA) & 9171 \\
\hline 3 & Rumah Tangga type B (RTB) & 2184 \\
\hline 4 & Rumah Tangga type C (RTC) & 200 \\
\hline 5 & Instansi (I), Perkantoran (P) & 108 \\
\hline 6 & Hotel Bintang (H) & 40 \\
\hline 7 & Hotel Non Bintang (M) & 67 \\
\hline 8 & Penginapan/Losmen (L) & 254 \\
\hline 9 & Restoran (R1) & 145 \\
\hline 10 & Restoran (R2) & 22 \\
\hline 11 & Restoran (R3) & 10 \\
\hline 12 & Komersial/Niaga (N1) & 990 \\
\hline 13 & Komersial/Niaga (N2) & 45 \\
\hline 14 & Komersial/Niaga (N3) & 19 \\
\hline 15 & Fasilitas Umum (FU) & 29 \\
\hline \multicolumn{2}{|c|}{ JUMLAH } & 13.356 \\
\hline
\end{tabular}

Sumber: UPT PAL, 2019

\section{$\underline{\text { Pengelolaan IPAL Denpasar }}$}

Badan Layanan Umum Pengelola Air Limbah (BLUPAL) yang dibentuk berdasarkan Peraturan Bersama Gubernur Bali, Bupati dan Walikota Denpasar No 37 A tahun 2006, Nomor 1 tahun 2006, Nomor 36 A Tahun 2006, tanggal Desember 2006 tentang Pengolaan Bersama Sistem Air Limbah Perpipaan dan keputusan Gubernur Bali Nomer 404 / 04 -f / HK/2007 tanggal 8 Mei 2007 tentang penetapan Pelakasana Badan Layanan Umum Pengelola Air Limbah. Untuk meningkatkan kualitas pelayanan kepada masyarakat di bidang pengelolaan air limbah, lembaga pengelola DSDP diharapkan kedepannya dapat menerapkan Pola Pengelolaan Keuangan Badan Layanan Umum (PPK-BLUD) dan sesuai amanat permendagri Nomor 6, Tahun 61 Tahun 2007 tentang Pedoman Teknis Pengelolaan Keuangan Bdan Layanan Umum Daerah disebutkan bahwa yang dapat menerapkan PPK BLUD adalah skpd atau unit kerja pada SKPD yang dibentuk sesuai peraturan perundang undangan.

Berdasarkan hal tersebut diatas dibentuklah UPT Pengelolaan Air Limbah Dinas Pekerjaan Umum Provinsi Bali Berdasarkan Perda No 4 tahun 2011 yang di jabarkan lebih lanjut dengan Pergub No 100 tahun 2011 Dan penelolaan DSDP tahap I sudah disesuaikan ke Pemprov Bali diteruskan Kepala Dinas Pekerjaan Umum dan UPT Pengelolaan Air limbah sebagai lembaga.

Bagan Sistem Pengelolaan IPAL Denpasar, dibawah Pemerintah Provinsi Bali, dismpaikan pada Gambar 3 sebagai berikut. 


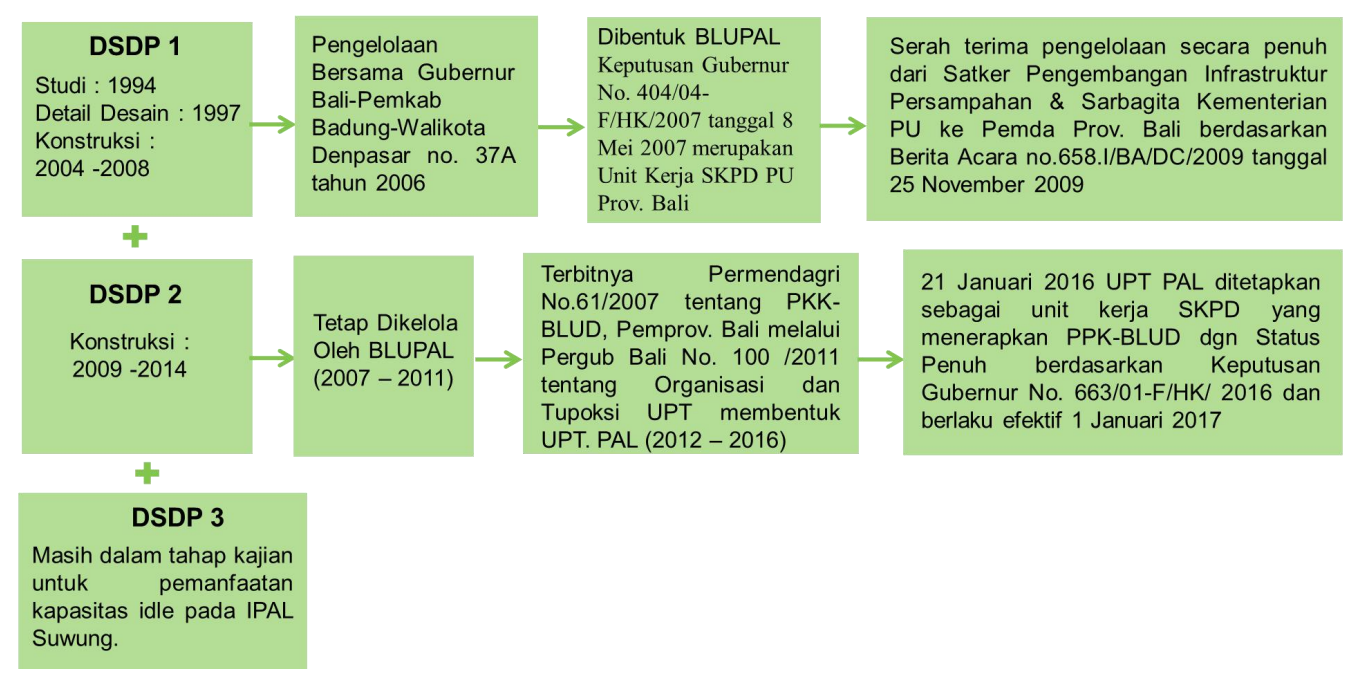

Gambar 3. Bagan Pengelolaan IPAL Denpasar (UPT PAL, 2019)

\section{Kajian Manajemen Aset IPAL Denpasar}

\section{$\underline{\text { Sistem Infrastruktur }}$}

Pengamatan Sistem Infrastruktur meliputi Infrastruktur, Daerah Pelayanan dan Pemakai Infrastruktur. Urian mengenai ketiga komponen Sistem Infrastruktur tersebut disampaikan pada Tabel 3 sebagai berikut.

Tabel 3. Sistem Infrastruktur IPAL Denpasar

\begin{tabular}{|l|l|}
\hline Infrastruktur & \multicolumn{1}{|c|}{ Gambaran } \\
\hline Area Pelayanan & $\begin{array}{l}\text { Instalasi Pengolahan Air Limbah (IPAL) dengan kapasitas } \\
\text { pengolahan } 51.000 \mathrm{~m} 3 / \text { hari; Jaringan pipa air limbah (sewer } \\
\text { network) } \varnothing 200-1200 \mathrm{~mm} \text { dengan panjang total } 130 \mathrm{~km} ; \\
\text { Rumah pompa (pumping station) di Sanur dan Kuta; } \\
\text { Sambungan Rumah (house connection) sebanyak 10.000 } \\
\text { unit }\end{array}$ \\
\hline $\begin{array}{l}\text { Wilayah pelayanan meliputi kawasan Denpasar, Sanur, dan } \\
\text { Kuta dengan total luas area 4.155 ha (termasuk DSDP III } \\
\text { yang masih dalam tahap pengembangan) }\end{array}$ \\
\hline Pengguna & $\begin{array}{l}\text { Melayani 153.900 jiwa yang terdiri dari konsumen rumah } \\
\text { tangga, instansi dan perkantoran, penginapan dan } \\
\text { perhotelan, restoran, komersial/ niaga, dan fasilitas umum }\end{array}$ \\
\hline
\end{tabular}

Fungsi dan Manfaat IPAL Denpasar

Hal kedua yang harus diamati dalam mengkaji Sistem Manajemen Aset Infrastruktur \& Fasilitas adalah mengamati Fungsi dan Manfaat Infrastruktur \& Fasilitas IPAL Denpsar.

Beberapa Fungsi Utama Infrastruktur \& Fasilitas IPAL Denpasar bisa disampaikan sebagai berikut.

- Menampung air limbah pada sambungan pelanggan.

- Mengalirkan air limbah di Instalasi Pengolahan Air Limbah di Suwung.

- Mengolah air limbah dengan memisahkan komponen organic dan anorganik.

- Mengolah dengan memisahkan komponen zat padat organic dengan komponen air.

- Membuang air ke badan air dalam keadaan sudah bersih.

- Memanfaatkan komponen zat padat sebagai pupuk organic. 
Tabel 4. Analisa Manfaat IPAL Denpasar

\begin{tabular}{|l|l|}
\hline Fungsi & Analisa \\
\hline $\begin{array}{l}\text { Pencegahan penyakit dan } \\
\text { gangguan kondisi ling- } \\
\text { kungan }\end{array}$ & $\begin{array}{l}\text { Kesehatan masyarakat dan lingkungan di Kota Denpasar dan } \\
\text { Badung yang terjaga dengan rendahnya angka penyakit yang } \\
\text { ditularkan melalui media air (waterborne disease) serta tidak } \\
\text { adanya gangguan lingkungan berupa bau dan sejenisnya } \\
\text { menunjukkan keberhasilan aset dalam menjalankan fungsinya } \\
\text { untuk mencegah penyakit dan gangguan kondisi lingkungan. }\end{array}$ \\
\hline $\begin{array}{l}\text { Menghindari kontaminasi } \\
\text { pasokan air bersih dan air } \\
\text { yang dapat dilayari }\end{array}$ & $\begin{array}{l}\text { Tidak adanya kontaminasi dari air limbah pada sistem IPAL } \\
\text { terhadap pasokan air bersih yang digunakan masyarakat sehari- } \\
\text { hari menunjukkan keberhasilan aset dalam menjalankan } \\
\text { fungsinya untuk mencegah kontaminasi pasokan air. }\end{array}$ \\
\hline $\begin{array}{l}\text { Pemeliharaan air bersih } \\
\text { untuk kelangsungan hidup } \\
\text { ikan, mandi, dan rekreasi }\end{array}$ & $\begin{array}{l}\text { Kualitas air bersih (air tanah dan air permukaan) yang terjaga } \\
\text { yang dapat digunakan untuk semua sendi kehidupan masyarakat } \\
\text { menunjukkan keberhasilan aset dalam menjalankan fungsinya } \\
\text { untuk memelihara air bersih. }\end{array}$ \\
\hline $\begin{array}{l}\text { Konservasi kualitas air untuk } \\
\text { penggunaan masa depan }\end{array}$ & $\begin{array}{l}\text { Kualitas dan kuantitas air bersih di Kota Denpasar dan Badung } \\
\text { yang terjaga kelestariannya sejak awal beroperasinya DSDP } \\
\text { menunjukkan bahwa fungsi konservasi air dalam pengolahan air } \\
\text { limbah telah berhasil dilaksanakan }\end{array}$ \\
\hline
\end{tabular}

Permintaan-Penawaran Infrastruktur

Analisis ketiga yang harus dilakukan dalam Kajian Manajemen ini adalah kajian Aspek Permintaan-Penawaran IPAL Denpasar. Kajian pada tahun 2019 menunjukkan bahwa Kapsitas IPAL adalah $51.000 \mathrm{~m} 3 /$ hari dan digunakan sebesar $35.000 \mathrm{~m} 3 /$ hari. Data tentang Analisis Penawaran-Permintaan disampaikan pada Tabel 5 sebagai berikut.

Tabel 5. Analisa Supply-Demand Infrastruktur

\begin{tabular}{|c|c|c|}
\hline & & Analisis \\
\hline \multirow[t]{3}{*}{ Penawaran } & Infrastruktur & Secara fisik infrastruktur dalam kondisi baik \\
\hline & Sistem Operasi & Sistem beroperasi dengan baik \\
\hline & Kapasitas & $\begin{array}{l}\text { Kapasitas unit } 51.000 \mathrm{~m}^{3} / \text { hari sedangkan debit rata-rata } \\
\text { operasional IPAL } 35.000 \mathrm{~m}^{3} / \text { hari, terdapat kapasitas idle } \\
\text { sebesar } 16.000 \mathrm{~m}^{3} / \text { hari yang rencananya dikembangkan } \\
\text { untuk DSDP III }\end{array}$ \\
\hline \multirow[t]{5}{*}{ Permintaan } & Kebutuhan & $\begin{array}{l}\text { Kebutuhan pengolahan limbah semakin bertambah dengan } \\
\text { banyak munculnya calon konsumen baru yang umumnya } \\
\text { berasal dari bisnis perhotelan, kuliner, dan tempat hiburan } \\
\text { sebagai akibat perkembangan sektor pariwisata }\end{array}$ \\
\hline & Penggunaan lahan, & Perubahan karakteristik konsumen membuat perubahan \\
\hline & Populasi, Kondisi & karakteristik air limbah sehingga diperlukan penyesuaian \\
\hline & Ekonomi & peralatan pada instalasi pengolahan limbah \\
\hline & Daerah Pelayanan & $\begin{array}{l}\text { Perluasan daerah pelayanan akan dilakukan dengan rencana } \\
\text { pengembangan DSDP III }\end{array}$ \\
\hline
\end{tabular}

\section{Operasional Infrastruktur}

Aspek keempat yang diamati dan dianalisis adalah Aspek Operasional IPAL Denpasar. Aspek ini sangat penting untuk diamati karena Kualitas Infrastruktur diukur dari Kinerja infrastruktur dalam menjalankan fungsinya. Infrastruktur dioperasikan sesuai dengan fungsinya. Analisis Operasional IPAL Denpasar disampaikan sebagai berikut.

a. Operasi IPAL Denpasar dilakukan secara rutin sesuai dengan SOP 
b. Penyaluran air limbah dari rumah pelanggan dibagi menjadi 3 kawasan yaitu Denpasar, Sanur dan Legian-Seminyak selama 24/7 (untuk kawasan Sanur dan Legian-Seiminyak menggunakan pumping station karena lokasi lebih rendah dari IPAL)

c. Pada IPAL kolam aerasi berupa kolam dengan kedalaman 4 meter yang terdiri dari 2 buah kolam dan dilengkapi dengan aerator sebanyak 11 buah, yang berfungsi sebagai pemasok udara (oksigen).

d. Di aerated lagoon, air limbah diaduk dengan aerator untuk menyuplai oksigen membantu bakteri-bakteri pengurai tetap hidup selama kurang lebih 2 hari untuk penetralisir limbah

e. Air dengan kandungan lumpur tersebut dialirkan ke kolam sedimentasi dengan kedalaman 2,4 meter untuk diendapkan sehingga lumpur - lumpur yang ada mengendap ke dasar kolam sedimentasi. Jika lumpur telah mengendap, maka akan dilakukan pengerukan untuk mengambil endapan +16 Jam.

$\underline{\text { Kerusakan dan Pemeliharaan Infrastruktur }}$

Hal kelima yang diamati dan dianalisis dalam penelitian ini adalah Aspek Kerusakan dan Pemelihraan IPAL Denpasar. Hal ini sangat penting, karena Kinerja Operasional Infrastruktur sangat dipengaruhi oleh Kondisi Fisik Infrastruktur. Sedangkan, Konisi Fisik Infrastruktur sangat dipengaruhi oleh Program Pemeliharaan Infrastruktur. Pemeliharaan Infrastruktur dilakukan untuk mengatasi Kerusakan Aset. berikut.

Program Pemeliharaan IPAL Denpasar secara garis besar bias disampaiakan sebagai

a. Pemeliharaan meliputi: Perawatan Aerator, Pembersihan Bar Screen, Pembersihan Control Panel, Perawatan Pompa, Pemeliharaan Wet Pit, Pemeliharaan House Inlet (HI), Pemeliharaan Sewer

b. Pemeliharaan IPAL Denpasar dilakukan secara rutin sesuai dengan SOP, jika ada keluhan dari masyarakat atau hal-hal yang mendesak dilapangan, seperti air meluap dari manhole karena pipa tersumbat, pompa macet pada wetpit, dll, akan dilakukan pemeliharaan sewaktu-waktu

Program Pemeliharaan IPAL Denpasar mengalami beberapa permasalahan Pemeliharaan sebagai berikut.

a. Rendahnya kesadaran masyarakat dalam mematuhi larangan dan himbauan untuk tidak membuang sampah pada saluran menyebabkan tersumbatnya pompa dan terganggunya sistem IPAL secara keseluruhan (adanya buangan sampah (plastik dan benda lain) ke saluran melalui bak HI atau manhole, juga melalui WC, bak cuci dapur dsb, Lemak yang terbuang dari dapur dan rumah makan, Manhole/bak HI dibuka pada saat hujan)

b. Pada stasiun pompa wet pit juga terjadi penyumbatan sampah dikarenakan pola pemakaian oleh pelanggan yang kurang disiplin dalam menerapkan larangan dan himbauan yang telah ditetapkan oleh Pemerintah Provinsi Bali.

c. Adanya perubahan komposisi dan spesifikasi limbah dari design dan rencana awal sistem yang dibangun dikarenakan perubahan komposisi konsumen sehingga memerlukan penyesuaian bahan dan jenis peralatan yang dipakai dalam operasional

Dampak Pengelolaan IPAL Denpasar

Hal terakhir yang dilakukan dalam penelitian ini adalah mencari tahu Dampak Keberadaan dan Pengelolaan IPAL Denpasar. Dampak dibagi kedalam Keuntungan Umum dan Pemanfaatan Hasil Olahan Limbah IPAL Denpasar. Kedua hal ini disampaikan sebagai berikut.

Keuntungan Umum dibangunnya dan pengelolaan IPAL Denpasar terdiri dari enam hal utama sebagai berikut. 
a. Meningkatkan kualitas lingkungan dan perairan (pantai, sungai dan air tanah) karena semua air limbah disalurkan ke jaringan pipa air limbah menuju kolam pengolahan air limbah. Adanya jaringan pipa air limbah tertutup dan terpusat mencegah masuknya air limbah ke pantai, sungai dan tanah, sehingga kualitas lingkungan dan perairan (pantai, sungai dan air tanah) dapat terjaga. Hasil studi kelayakan IPAL juga mengungkapkan, dengan adanya IPAL dapat mengurangi tingkat pencemaran sampah ke pantai dan laut. Dengan IPAL tingkat pencemaran perharinya sebanyak 106 ton per hari, sedangkan tanpa IPAL tersebut sebanyak 128 ton setiap harinya.

b. Melalui pembangunan IPAL, air limbah terbuang melewati pipa IPAL menuju kolam pengolahan air limbah sehingga lebih mudah dipantau oleh pemerintah daerah dan kualitas lingkungan dapat tetap terjaga.

c. Melalui pembangunan IPAL, kualitas lingkungan dapat lebih terjaga sehingga kesehatan masyarakat juga dapat terjaga dan dapat terhindar dari sumber penyakit seperti diare, disentri, muntaber, dll.

d. Rumah/perumahan baru yang dilewati oleh saluran pipa IPAL tidak perlu membangun septic tank baru dikarenakan air limbah dari WC dibuang melalui pipa IPAL.

e. Melalui pembangunan IPAL kualitas lingkungan dan kesehatan masyarakat dan wisatawan di Bali lebih terjaga sehingga citra pariwisata Bali di Dunia Internasional dapat meningkat. Direktur Jenderal (Dirjen) Cipta Karya Budi Yuwono mengatakan, keberadaan instalasi Pengolahan Air Limbah (IPAL) Denpasar Sewerage Development Project akan meningkatkan pendapatan Bali dari sektor pariwisata. Berdasarkan hasil studi kelayakan proyek DSDP, pendapatan pulau dewata pada 2009 akan meningkat menjadi Rp 706,478 miliar dengan adanya DSDP. Sementara tanpa adanya IPAL tersebut pendapatan diprediksi hanya Rp 313,99 miliar.

f. Pembangunan DSDP digunakan sebagai pusat pendidikan untuk menanamkan kesadaran terhadap lingkungan dan pusat penelitian bagi para pelajar, mahasiswa dan masyarakat umum.

Akhirnya disampaikan disini pemanfaatan Hasil Olahan Limbah IPAL Denpasar dapat dimanfaatkan sebagai berikut.

a. Bahan baku air bersih

b. Mobil pemadam kebakaran menggunakan air hasil olahan limbah IPAL untuk mengisi tangki mobil.

c. Air hasil olahan limbah IPAL digunakan untuk penyiraman tanaman kota yang dibawa oleh truk penyiram tanaman milik pemerintah kota.

d. Air hasil olahan limbah IPAL sering dimanfaatkan untuk mencuci truk pengangkut sampah.

e. Pada lahan sekitar kolam pengolahan air limbah IPAL Denpasar, air hasil olahan IPAL dimanfaatkan untuk pengairan tanaman seperti kangkung.

\section{KESIMPULAN}

Penelitian Kajian Awal Manajemen Aset bagi IPAL Denpasar telah berhasil diselesaikan. Penelitian ini telah menghasilkan beberapa kesimpulan pokok sebagai berikut.

- Sudah ada SOP untuk program Pengoperasian dan Pemeliharaan.

- Masalah utama pengoperasian dan pemeliharaan terutama disebabkan oleh kandungan obyek platik pada Limbah Tinja.

- Semua Fungsi Utama bias dijalankan dengan baik, menampung, mengalirakan dan mengolah limba tinja. 
- IPAL Denpasar meberikan beberapa manfaat utama : perbaikan kondisi air tanah; menyediakn fasilitas bagi kompleks perumahan, hotel, restoran, pusat niaga baru; air bagi penyiriman tanaman kota, pupuk organic bagi tanaman di Komples IPAL Denpasar, penyediaan air bersih bagi pertanian kangkung.

\section{DAFTAR PUSTAKA}

Anonim (2019). Pedoman Pengoperasian \& Pemeliharaan Instalasi Pengolahan Air Limbah (IPAL). http://www.sanitasi.net/pedoman-pengoperasian-dan-pemeliharaan-instalasipengolahan-air-limbah-ipal. diunduh 14 Agustus 2019. Jam 18.30 WIB.

Hariyono,A. (2007). Prinsip dan Teknik Manajemen Kekayaan Negara. Departemen Keuangan Republik Indonesia. Badan Pendidikan dan Pelatihan Keuangan Umum.

Munizar, R. (2018). Manajemen Aset Infrastruktur Daerah untuk Pembangunan Berkelanjutan. http://pedomanbengkulu.com/2018/08/manajemen-aset-infrastruktur-daerah-untuk pembangunan-berkelanjutan. diunduh 13 Agustus 2019. Jam 08:51 WIB.

Nawawi, H. (2006). Evaluasi dan Manajemen Kinerja di Lingkungan Perusahaan dan Industri. Gadjah Mada University Press. Yogyakarta.

Pergub Bali 38/2012. Peraturan Gubernur Bali Nomor 38 Tahun 2012 Tentang Petunjuk Pelaksanaan Perda Prov Bali No. 2 Tahun 2011 Tentang Retribusi Jasa Umum.

Permen PUPR 04/2017. Peraturan Menteri Pekerjaan Umum dan Penataan Ruang Nomor 04/PRT/M/2017 tentang Penyelenggaraan Sistem Pengelolaan Air Limbah Domestik.

PP 27/2014. Peraturan Pemerintah Republik Indonesia Nomor 27 Tahun 2014 tentang Pengelolaan Barang Milik Negara/Daerah.

Siregar, D (2004). Manajemen Aset. Gramedia Pustaka Utama. Jakarta

Soemitro, R.A.A. \& Suprayitno, H. (2018). "Pemikiran Awal tentang Konsep Dasar Manajemen Aset Fasilitas". Jurnal Manajemen Aset Infrastruktur \& Fasilitas, Volume 2, Suplemen 1, Juni 2018, Hal. : 1-14.

Spellman, F.R. (2003). "Handbook of Water and Wastewater Treatment Plant Operations". Boca Raton: CRC Press LLC. New York Washington, D.C.

Sugiama, A.G. (2013). Manajemen Aset Pariwisata. Guardaya Intimarta. Bandung.

Suprayitno, H. \& Soemitro, R.A.A. (2018). "Preliminary Reflexion on Basic Principle of Infrastructure Asset Management”. Jurnal Manajemen Aset Infrastruktur \& Fasilitas, Volume 2, Nomer 1, Maret 2018, Hal. : 1-10.

Suprayitno, H. \& Soemitro, R.A.A. (2019). "Reflection on Basic View of Public Infrastructure for Infrastructure Asset Management in Indonesia". Jurnal Manajemen Aset Infrastruktur \& Fasilitas, Volume 3, Sup 1, Juni 2019.

UPT PAL.(2009). Data Primer Pengolahan Air Limbah DSDP Provinsi Bali. Unit Pengelola Teknis Pengelohan Air Limbah. 
(e)ISSN 2615-1847 $\quad$ (p)ISSN 2615-1839

Jurnal Manajemen Aset Infrastruktur \& Fasilitas - Vol. 3, Sup. 2, Desember 2019 